\title{
Iberian distribution of some little known bat species
}

\author{
by C. IBAÑEZ', A. GUILLEN' ${ }^{\prime}$, R. FERNANDEZ ${ }^{2}$, \\ J.L. PEREZ' ${ }^{\prime}$ and S.I. GUERRERO' \\ 'Estación Biológica de Doñana, CSIC. Apartado 1056, \\ E-41080 Sevilla, Spain \\ 2 c/Fernando VII, 1. E-36003 Pontevedra, Spain
}

Summary. - The distributional status of 9 species of bats in the Iberian Peninsula are reviewed and completed. Up to now these species were poorly known due to inadequate surveys or their true rarity. These species are: Myotis bechsteini, $M$. emarginatus, $M$. mystacinus, Nyctalus lasiopterus, N. leisleri, N. noctula, Pipistrellus nathusii, P. (Hypsugo) savii and Barbastella barbastellus.

Résumé. - La répartition de neuf espèces de chauves-souris dans la Péninsule lbérique est révisée et complétée. Jusqu'à présent, cette répartition était presque inconnue en raison de leur réelle rareté ou de l'absence de prospections. Il s'agit de: Myotis bechsteini, M. emarginatus, M. mystacinus, Nyctalus lasiopterus, N. leisleri, N. noctula, Pipistrellus nathusii, P. (Hypsugo) savii et Barbastella barbastellus.

Studies on Chiropteran fauna in the Iberian Peninsula have recently undergone an important advance with the appearance of various papers providing regional syntheses : Cantabria (Meijide 1979), Cataluña (Carol et al. 1983), Galicia (Sánchez-Canals and Guitián 1988), Valencia (Serra-Cobo and Faus 1989) and Portugal (Palmeirim 1990). However, the information available on an elevated number of species, above all non cave-dwellers, is scarce. This paper offers results obtained during the last few years on the chorology of Iberian bat species which are poorly known. A compilation of bibliographic information is provided including references given by publications which are difficult to find.

\section{MATERIAL AND METHODS}

The new information presented here comes from two main sources: first, a review of collections with specimens of spanish bats not previously cited (Estación Biológica de Doñana, Sevilla, EBD; Departamento de Zoologia, Facultad

NIammalia, $t .56, n^{\circ} 3,1992$. 
de Biología, Universidad de Oviedo, Oviedo, FBS ; Unidad de Zoología Aplicada, Madrid, UZA ; Senckenberg Museum, Frankfurt, SMF); and second observations or captures of specimens later set free. The information includes the total number of specimens in each location (municipal district) and between parenthesis is given the specimens conserved in collections and the year of the capture or observation, when known. In order not to excessively lengthen the text, under "References " only the minimum number of references including all known records will be cited. The maps represent the locations distinguishing records from the bibliography which are divided into old (captures and observation before 1950) and modern (generally after 1960). Observations refering to the remains of bones are also distinguished. Records of doubtful validity are marked with a question mark. Reports in which a concrete location is not mentioned are not included in the maps although they are under "References" (such is the case of all the reports of González et al. 1986, in Asturias).

\section{ACCOUNTS OF SPECIES}

Myotis bechsteini (Kuhl, 1818).

New records: Cáceres, Madrigal de la Vera, I skull in a Tyto alba pellet (1 EBD, 1987). Cádiz. Grazalema, 1 (1 EBD, 1987). Málaga, Cortes de la Frontera, 2 (1 EBD, 1987-90).

References : Gómez (1932), Meijide (1979), Otero et al. (1978), Palmeirim (1990), Sánchez-Canals and Guitián (1988), and Tupinier (1975).

This is a species known in the Iberian Peninsula in very few reports, almost all in the northern half. A good part are old records and remains from bones (Fig. 1). The locations marked here in the extreme south of Iberia constitutes the southernmost limit known for the species. The zones of capture in Grazalema as well as in Cortes de la Frontera are covered by forest (Abies pinsapo anc. Quercus faginea in the former and $Q$. suber and $Q$. canariensis in the latter) with a high proportion of old trees. $M$. bechsteini appears in the whole peninsula without an apparent inferior limit of elevation ( $150 \mathrm{~m}$ in Cortes de la Frontera). All the captures are located in forest zones especially well conserved and relatively damp.

\section{Myotis emarginatus (Geoffroy, 1806).}

New records: Alicante, Monóvar, colony \pm 200 (1988). Cáceres, Grimaldo, 1 (1 EBD, 1987). Asturias, La Foz, 1 (1 FBO, 1981); Paredes, 1 (1 UZA, 1984). Cádiz, Grazalema, 3 (2 EBD, 1987) ; Jerez de la Frontera, colony \pm 20 (1989); Jimena de la Frontera, I (1989). Castellón, Pina del Montalgrao, 1 (1988); Ain, colony \pm 150 (1988); Fredes, 1 (1988). Granada, Arenas del Rey, colony \pm 100 (15 EBD, 1983-85); Huétor-Santillán, 2 (2 EBD, 1963); Lanjarón, 2 (2 EBD, 1983); Loja, 1 (I EBD, 1987). Madrid, Aranjuez, 7 (7 UZA, 1978-81); Sierra de Guadarrama, I (1 UZA, 1974). Málaga, Mollina, colony \pm 60 (1989) ; Ronda, 2 (2 EBD, 1987). Murcia, Zarzadilla de Totana, 2 (2 EBD, 1987). Pontevedra, Figueirido, 1 (1 FBO). La Rioja, El Rasillo, 1 (1 EBD, 1987). Valencia, Casas del Rio, colony \pm 20 (1988); Cortes de Pallas, 1 (1988); Ayora, 1 (1988); Gestalgar, colony \pm 10 (1988); Tuéjar, colony \pm 20 (1989).

References: Gisbert and Melendro (1978), González el al. (1986), Ibáñez (1988), Meijide (1979), Otero et al. (1978), Palmeirim (1990), Paz and Lope (1985), Samarra and Carol (1986), Sánchez-Canals and Guitián (1988), Serra-Cobo and Faus (1989), and Serra-Cobo et al. (1986). 

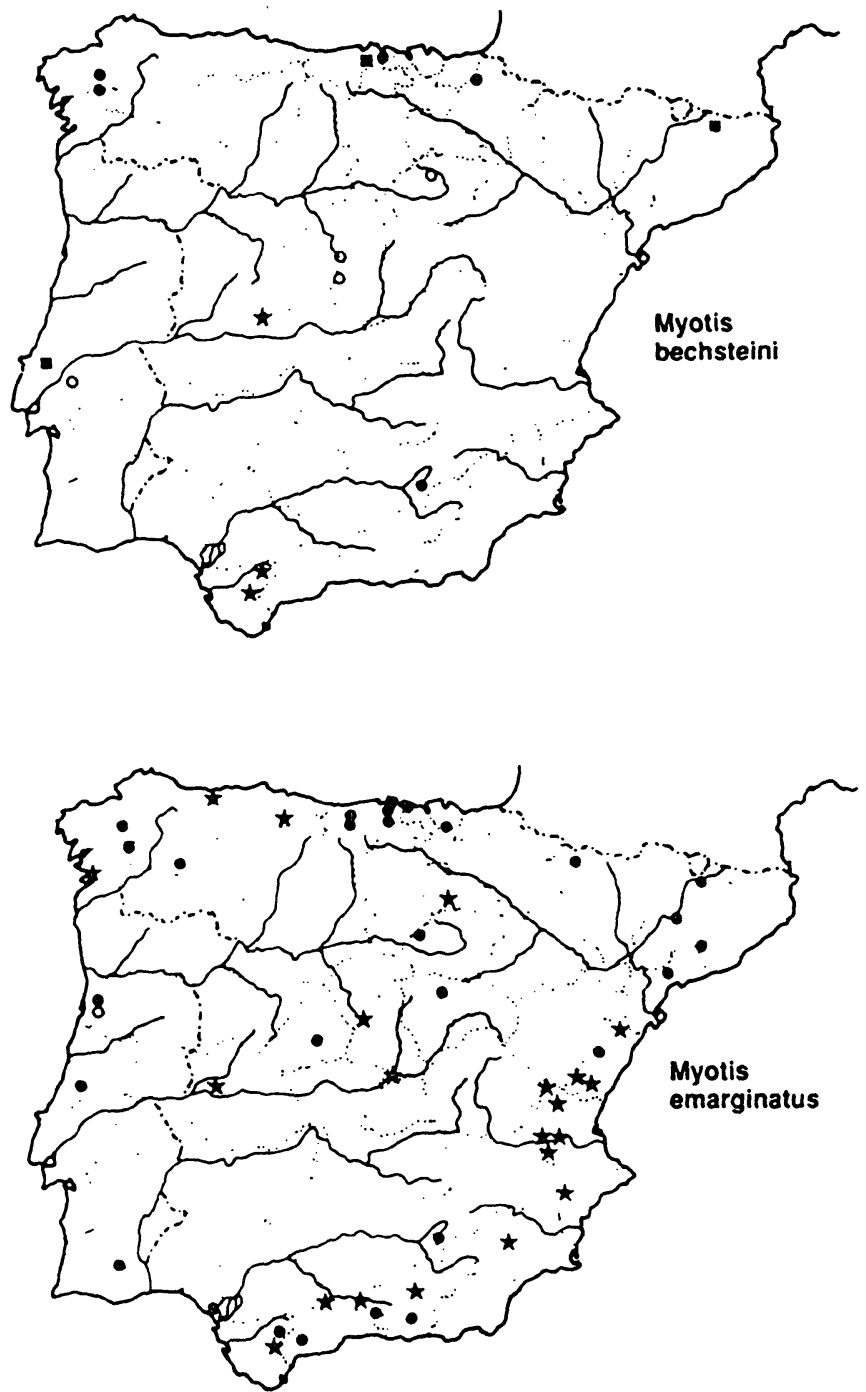

Fig. 1. - Iberian records of Myotis bechsteini and M. emarginatus. Open circles, literature references earlier than 1950 ; closed circles, literature references later than 1950 ; closed squares, literature references of bones later than 1950 ; closed star, new records.

This was one of the latest bat species to be reported in Spain (Balcells 1964). The known locations and those cited here indicate that it is a species widely distributed in all of Iberia (Fig. 1). At least in Andalucia and Comunidad Valenciana, it is relatively frequent, but in lower, drier and coastal zones with thermomediterranean vegetation where it is rare. 
Myotis mystacinus (Kuhl, 1819).

New records: Navarra, Isaba, 1 (1 UZA, 1972). Palencia, Alba de los Cardaños, I (1 UZA, 1980). La Rioja, Ortigosa, 2 (1 UZA, 1972 ; I EBD, 1984) ; El Rasillo, 5 (5 EBD, 1987-88) ; Villanueva de Cameros, 1 (1 UZA, 1974).

References: Gómez (1932), González et al. (1986), Meijide (1979), and Palmeirim (1990).

The shape of the penis of 5 males examined indicate they are of this species rather than $M$. brandti. $M$. mystacinus is a species especially rare in the Iberian Peninsula in spite of being one of the most common bats in most of Europe. There were six known records with an exact location, four of which are before 1932. The only recent reports of complete specimens are in Cantabria (Meijide 1979) and Asturias (González et al. 1986) although in the latter case no exact location is given. All the known Iberian localities are placed in mountainous areas of the peninsular northern half (Fig. 2).

\section{Nyctalus lasiopterus (Schreber, 1780).}

New records: Cádiz, Jerez de la Frontera, Sierra del Aljibe, 8 (1 EBD, 1987-90). Huelva, Almonte, Palacio de Doñana, 1 skull in a Tyto alba pellet (l EBD). Málaga, Cortes de la Frontera, 36 (8 EBD, 1987-90). La Rioja, Ortigosa, 4 (4 EBD, 1984-85). Sevilla, Sevilla (Parque de Maria Luisa), two colonies in trees of undetermined number of individuals ( 1 found run over EBD, 12.4.90).

References: González et al. (1986), Ibánez and Benzal (1984), and Palmeirim (1990).

This species is considered one of the rarest in Europe. In Iberia the records published are scarse and in general very recent. The locations presently known indicate that the species is widely distributed throughout the entire peninsula (Fig. 2). From sea-level (Doñana) up to $1,350 \mathrm{~m}$ (Ortigosa), it is relatively frequent, at least in some locations. All of the locations where specimens have been examined are populated by old trees with hollows and in general are situated in forests. The exceptions are in the zone of Doñana where there are very old Quercus suber but with a very low density and in the Parque de Maria Luisa in Sevilla which is a forest micro-environment in an urban setting.

Nyctalus leisleri (Kuhl, 1818).

New records : Cádiz, Alcalá de los Gazules, 5 (1989-90); Grazalema, 6 (1 EBD, 1987); Jerez de la Frontera (Sierra del Aljibe), 57 (11 EBD, 1987-90); Jimena de la Frontera, 4 (1989). Málaga, Cortes de la Frontera, 50 (1 EBD, 1987-90); Parauta, 1 (1 EBD, 1987). La Rioja, Ortigosa, 25 (11 EBD, 1984-87); El Rasillo, 6 (1990).

References: Arrizabalaga and Montagud (1984), Benzal (1984), and Palmeirim (1990).

Although this species has been known in Portugal since ancient times (Palmeirim 1990), it was the last of the chiropterans found in Spain (Benzal 1984; Arrizabalaga and Montagud 1984). The locations presently known show that it has a very wide distribution in the whole peninsula (Fig. 3). The new locations presented are found between 150 and $1,350 \mathrm{~m}$ and are characterized by a significant forest cover with a high density of old trees. In spite of being considered a rare species, in the locations where more intense surveys have been carried out (the mountains of Cádiz and Málaga and Sierra de Cameros) it has turned out to be very common. 

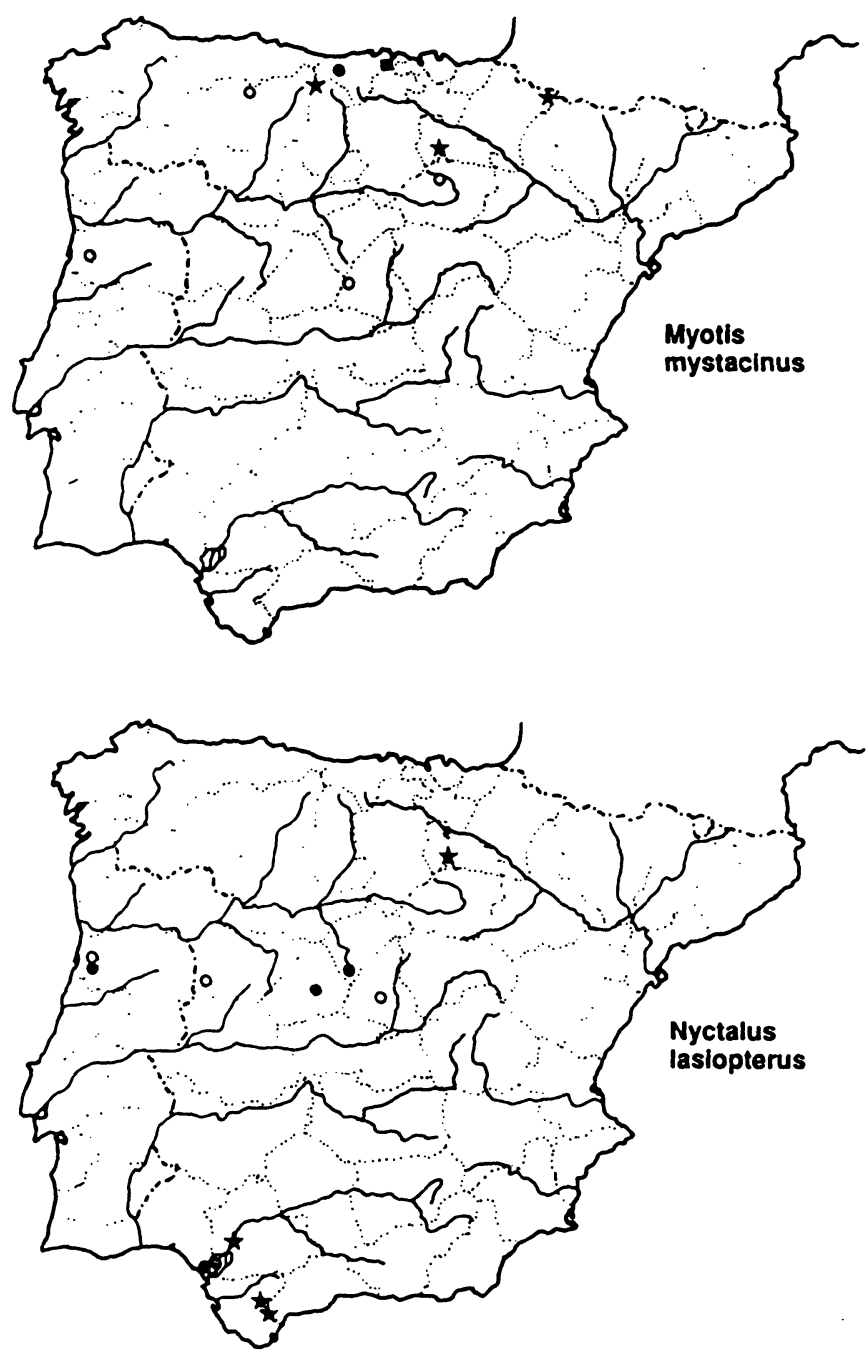

Fig. 2. - Iberian records of Myotis mystacinus and Nyctalus lasiopterus. Symbols as in Fig. 1.

Nyctalus noctula (Schreber, 1774).

New records: Cantabria, Asón, 1 (1 UZA, 1970); Valladolid, San Román de Hornija, 1 (1 EBD, 1983).

References: Boscá (1915), Cabrera (1914), Noval (1982) and Palmeirim (1990).

The abundance of this species in most of Europe contrast with its extreme rarity in the Iberian Peninsula. In Portugal there is only one trust worthy report (Palmeirim et al. 1979). In Spain the only exact location from which specimens 
were conserved was Sevilla (Cabrera 1914). There are specimens in the Museo Nacional de Ciencias Naturales in Madrid (Ibáñez and Fernández 1989) and the British Museum. The rest of the Spanish records have to be considered with reservations due to the possibility of mistaken identification with Eptesicus serotinus and $N$. lasiopterus as has happened in Portugal (Palmeirim et al. 1979). The Spanish specimens are very old, the end of the last century and the beginning of this, so the reports given here are the first in 75 years. The available data seems to show that $N$. noctula could exist in the entire peninsula (Fig. 3 ) although in a reliable and sporadic way without any special requirements of habitat or climate.

\section{Pipistrellus nathusii (Keyserling et Blasius, 1839).}

New records: Valencia, Silla, I (I SMF).

References : Cabrera (1914), Carol et al. (1983), Ibáñez and Fernández (1989), and Palmeirim (1990).

The known records are very old, before 1920. According to Palmeirim (1990), the Portugese reports are probably owing to mistaken identifications and the same may be true at least of some of the Spanish. Presently only four specimens are conserved in Iberia: three in the Museo Nacional de Ciencias Naturales in Madrid, two of them without location which could be one of those cited by Cabrera (1914) and another from Muriedas (Cantabria) the year of which is unknown. The fourth specimen (identified by Dr. H. Vierhaus of SMZ) is the one mentioned in Silla. With reservations due to the doubtful validity of the old reports, $P$. nathusii extends throughout the northern half of the peninsula (Fig. 4), always sporadically.

\section{Pipistrellus (Hypsugo) savii (Bonaparte, 1837).}

New records: Alicante, Alcoi, 1 (1988). Almeria, Canjáyar, 10 (10 EBD, 1987) ; Dalias, 8 (8 EBD, 198/) ; Gérgal, 6 (6 EBD, 1987): Tabernas, 4 (4 EBD, 1987). Cádiz, Cortes de la Frontera, 1 (1989); Grazalema, 4 (2 EBD, 1987). Castellón, Atzeneta del Maestrat, 1 (1988); Fredes, 14 (1988) ; Segorbe, 6 (1988). Granada, Capileira, 2 (2 EBD, 1986); Loja, 1 (1 EBD, 1986) ; Orgiva, 5 (5 EBD, 1986). Soportujar, 2 (2 EBD, 1984); Ventas de Zafarraya, 9 (9 EBD, 1987). Huesca, Benasque, 1 (1987); Sabiñánigo 1 (1 UZA, 1972). Málaga, Mollina, 4 (1988); Parauta, 2 (2 EBD, 1987); Tolox, 11 (5 EBD, 1987). La Rioja, Ortigosa, 8 (5 EBD, 1985-87); El Rasillo, I (1 EBD, 1987). Segovia, Riofrio, 1 (1 UZA, 1973). Valencia, Ayora, 1 (1988); Requena, 1 (1988).

References : Arrizabalaga and Montagud (1984), Bauer (1956), Benzal (1984), Boscá (1915), Cabrera (1914), Carol el al. (1983), Gómez (1932), González el al. (1986), González-Prieto el al. (1986), Ibáñez and Fernández (1989), Otero et al. (1978), and Palmeirim (1990).

This species was known in few locations, above all in the northern half of the peninsula, and mostly in old reports (Fig. 4). The information presented here indicates that this bat is common in mountainous zones next to the Mediterranean coast. New reports include locations between $150 \mathrm{~m}$ (Cortes de la Frontera) and $2,400 \mathrm{~m}$ (Capileira), the most frequent and abundant being above $600 \mathrm{~m}$.

\section{Barbastella barbastellus (Schreber, 1774).}

New records : Asturias, Infiesto, 1 (1 FBO). Castellón, Vilafranca del Maestrat, 2 (1988). Jaén, Cazorla, 1 (1990). Guadalajara, El Cardoso, 1 (1 EBD, 1968). La Rioja, El Rasillo, 3 (2 EBD, 1987-90).

References: Balcells (1965), Balcells (1971), Bauer (1956), Carol et al. (1983), Galán (1970), Gómez (1932), González et al. (1986), González-Pietro et al. (1986), Ibáñez and Fernández (1989), Meijide (1979), Palmeirim (1990), Samarra Carol (1986) and Villota and Galán (1970). 

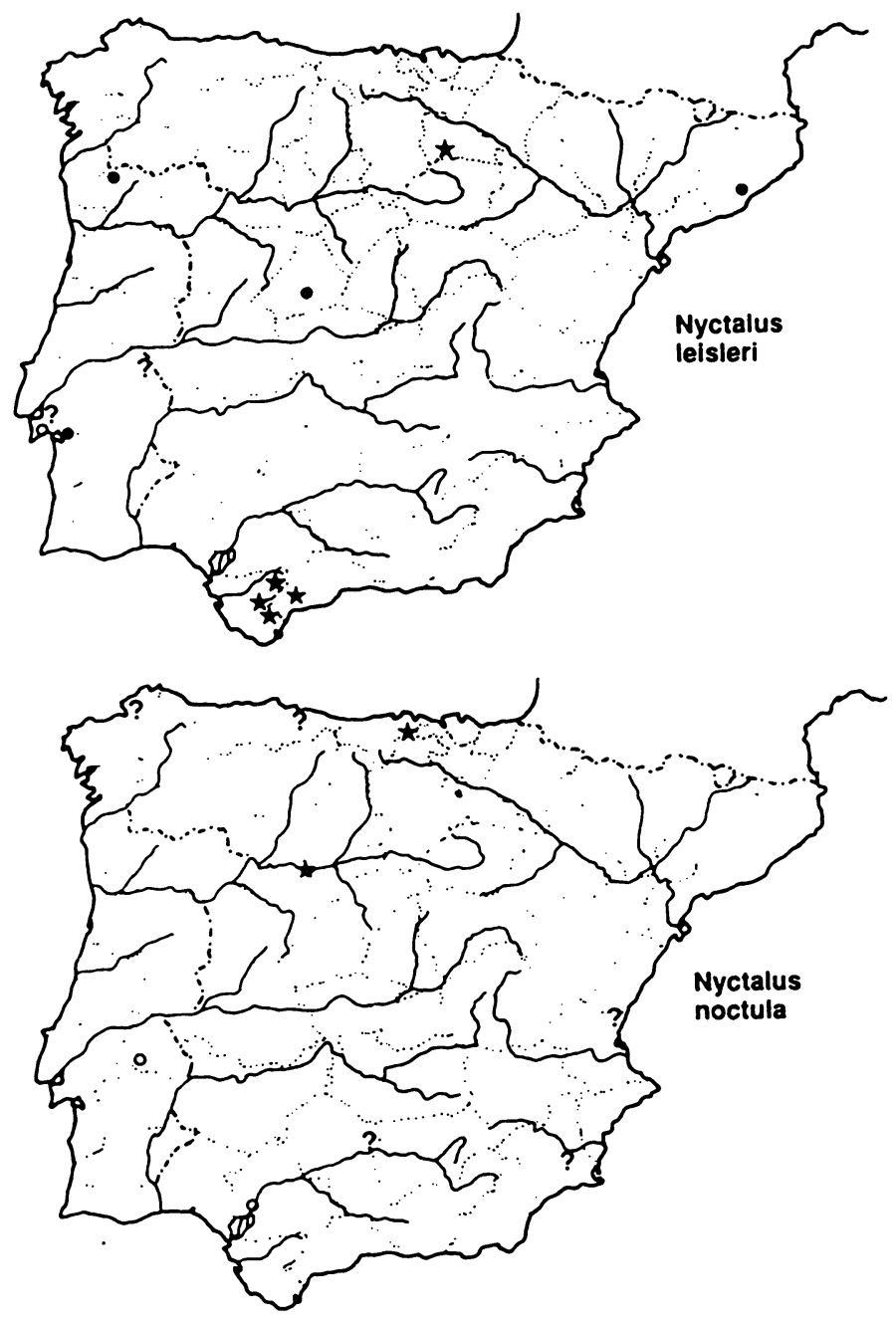

Fig. 3. - Iberian records of Nyctalus leisleri and N. noctula. Symbols as in Fig. 1.

B. barbastellus has been recently reported with relative frequency in the Northern third of the peninsula. In the center zone the reports are generally from old captures (Fig. 5). The report from Valencia (Boscá 1915) could refer to the city or the province. The one from Mortoro (Córdoba) (Martínez 1881) must be considered doubtful since, in spite of the fact that the identification of the species offers no problems, the author frequently made mistakes. In this particular case, he considers $B$. barbastellus frequent in the bell-towers of the churches of the zone which seems unlikely. It seems that in the southern half of the peninsula the species is much rarer, scarse and local. The most reliable southernmost locations in the peninsula are only known in Portugal (Palmeirim 1990) and the new one in Cazorla. 


\section{DISCUSSION}

Some of the species mentioned, such as $P$. nathusii and $N$. noctula, are extremely rare in the Iberian Peninsula. In the former case, the rarity could be justified by the fact we are dealing with a migratory central european bat whose winter headquarters in Western Europe is in France (Brosset 1990). It could be one of the few specimens found in Iberia as a marginal product of these migratory movements. The same might be the case with $N$. noctula, a species which also undertakes important migrations. However, the fact that the two females in Spain without exact location deposited in the British Museum are apparently not quite adult (J.E. Hill, personal comment), would indicate that they breed in the Iberian Peninsula. To this it should be added that if the identification is correct, the specimens reported by Boscá (1915) were nursing females. Another possible cause for the rarity of this species in Iberia might be related to the apparent greater abundance of the other two Nyctalus. $N$. noctula can be substituted by $N$. lasiopterus and $N$. leisleri in Mediterranean latitudes.

M. mystacinus is restricted to the Northern half of the peninsula in zones with oromediterranean, subatlantic or atlantic vegetation (Ozenda et al. 1979). $B$. barbastellus has been found more towards the south and most of the reports, except those of Palmeirim (1990) and Bauer (1956), are also located in zones with the above-mentioned types of vegetation.

The rest of the species considered are widely distributed throughout the peninsula. Some, such as $M$. emarginatus and $P$. savii are frequent while others are locally abundant when the habitat is adequate as in the case with both Nyctalus. The lack of existing information is without doubt due to samplings biased in favor of the most conspicuous cave-dwelling bats.

The extension of the distribution of some species throughout the entire Iberian Peninsula as well as their apparent greater abundance in the southern half makes it advisable to reconsider the biogeographic classification of Carol et al. (1983). This classification includes some of these species in groups typical of central Europe $(N$. leisleri) and the North of the Mediterranean Sea $(M$. emarginatus, $N$. lasiopterus and $P$. savii).

With the information presented we can define chorologically the species considered in the context of the Western Mediterranean and the Iberian Peninsula. Nyctalus noctula and $P$. nathusii are Central European species, occasional or sporadic in Iberian fauna. Myotis mystacinus and Barbastella barbastellus seem to be of Central European filiation and appear with a certain frequency in the Northern third of the Peninsula penetrating the south in the mountains with oromediterranean vegetation. Myotis bechsteini also seems to be typical of Central European fauna although it penetrates southward to humid deciduous mediterranean forests. Nyctalus leisleri, $N$. lasiopterus and $M$. emarginatus appear in this context as being chorologically related as they occupy a similar latitudinal strip (Southern Europe and the North of Maghreb) in which perhaps M. emarginatus goes farther north. Pipistrellus savii is present in the circummediterranean mountains above $500 \mathrm{~m}$. 

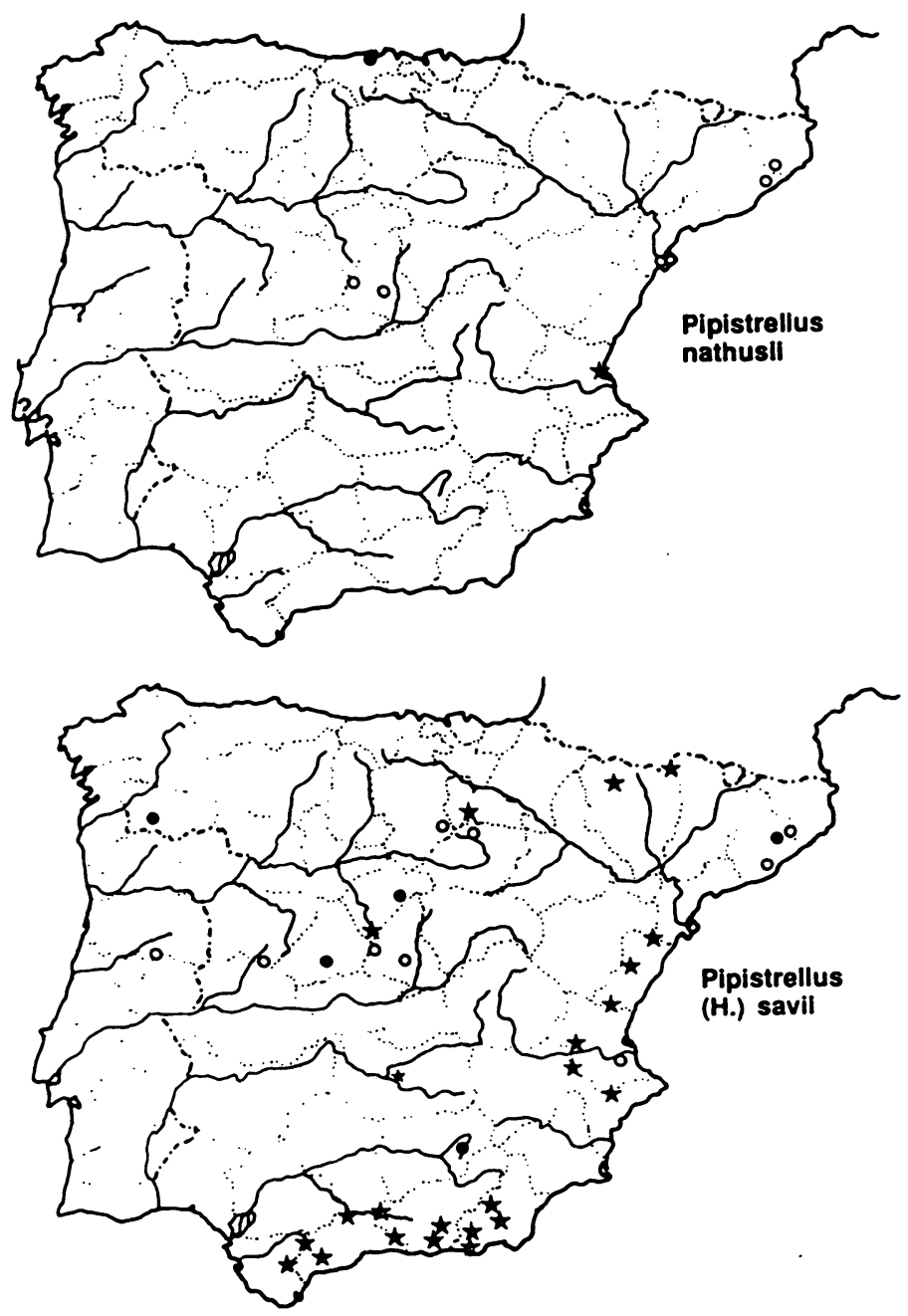

Fig. 4. - Iberian records of Pipistrellus nathusii and P. (Hypsugo) savii. Symbols as in Fig. 1.

Sevilla (1988) records the presence in the Quaternary of $M$. bechsteini, $M$. emarginatus, $N$. lasiopterus and $N$. leisleri in Southern Iberian locations very near some of those mentioned here. Relating this with the chorological information available at this time, the author proposes a reduction of the distribution area throughout the Quaternary due, in some cases, to a regression of the forestal areas in the Iberian Peninsula. Although the limited information on the distribution of these species in the Quaternary does not allow us to affirm this suggestion, the information presented partially supports it since the presence of some of these bats is strongly associated with forestal environments and their present distribution may be fragmented but it extends throughout the entire Iberian Peninsula. 


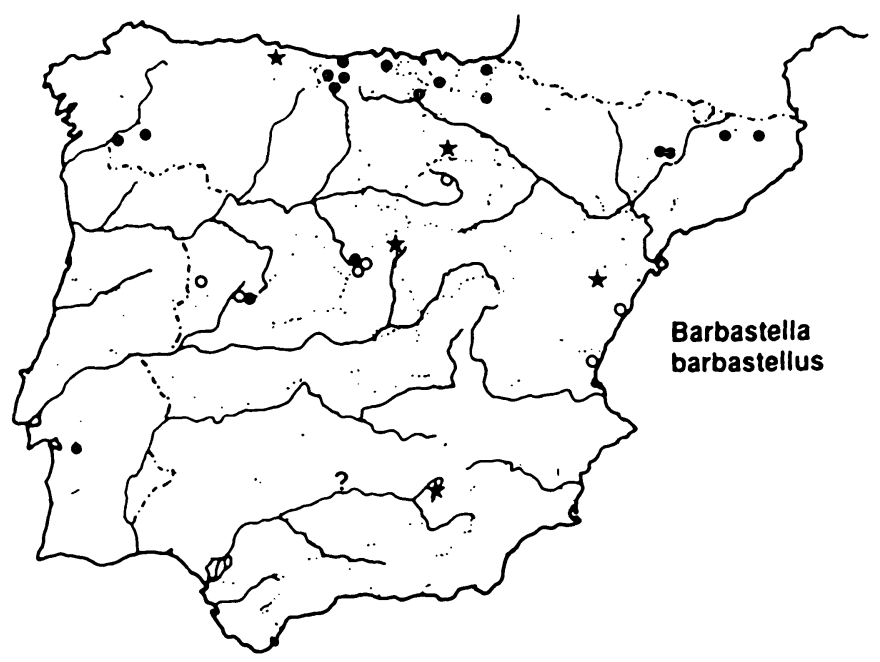

Fig. 5. - Iberian records of Barbastella barbastellus. Symbols as in Fig. 1.

\section{ACKNOWLEDGEMENTS}

We thank the curators and assistants who permitted examination of specimens in their care and Dr. H. Vierhaus (SMZ) for his information on $P$. nathusii. A great deal of the information here presented was obtained in the course of projects financed by CICYT (PB87-0405), Junta de Andalucia and Generalitat Valenciana. Four of the authors were granted fellowships by the Ministerio de Educación y Ciencia (A.G.), ICONA-CSIC (R.F.), Junta de Andalucia (J.L.P.) and ICI (S.I.G.).

\section{BIBLIOGRAPHY}

Arrizabal.AciA, A. and A. Montaciud, 1984. - Notes sobre la fauna de quiropters del Vallés Oriental (Barcelona, Catalunya). Una nova especic per a la fauna espanyola. Misc. Zool., 8 : 307-310.

BAi.cel.l.s, E., 1964. - Sobre nuevas citas de mamíferos de la Península Ibérica. Bol. R. Soc. Española Hist. Nat. (Biol.), 62: 367-368.

BAi.cel.t.s, E., 1965. - Nuevos datos sobre murciélagos raros en cuevas españolas. Misc. Zool., 2 : 149-160.

BAI.CEI.I.S, E., 1971. - Murciélagos y otros animales guanobios de Itxina (Vizcaya). Kobie (Bilbao), 3 : 1-3.

Bauer, K., 1956. - Zur Kenntnis der Fledermausfauna Spaniens. Bonn. Zool. Beiträge, 7: 296-319.

Benzal, J., 1984. - Presence de la nyctale de Leisler Nyctalus leisleri (Kuhl, 1818) a Gredos (Espagne centrale). Mammalia, $48: 461$.

BoscA, E., 1915. - Comentarios sobre mamiferos de la región valenciana comprendidos en la "Fauna Ibérica" de Don Angel Cabrera. Mem. R. Soc. Española Hist. Nat., 10: 125-146. 
Brosset, A., 1990. - Les migrations de la pipistrelle de Nathusius, Pipistrellus nathusii, en France. Ses incidences possibles sur la propagation de la rage. Mammalia, $54: 207-212$.

Cabrera, A., 1914. - Fauna Ibérica. Mamíferos. Museo Nacional de Ciencias Naturales, Madrid.

Carol, A., F.J. Samarra and E. Balcells, 1983. - Revisión faunística de los murciélagos del Pirineo Oriental y Catalunya. Monografias Inst. Estud. Pirenaicos, 112 : 1-106.

GAL.AN, C., 1970. - Aportación al conocimiento de los quirópteros cavernicolas del Pais Vasco. Munibe, 22: 61-66.

Gisbert, J. and J. Melendro, 1978. - Datos sobre el Myotis emarginatus en la peninsula Ibérica. Doñana Acta Vert., 5: 113-114.

GoMeZ, L., 1932. - Mamiferos de la provincia de Soria. Bol. R. Soc. Española Hist. Nat., 32 : 231-235.

Gonzalez, F., A. Gonzal.ez and R. Rodriguez, 1986. - Situación del atlas provisional de los quirópteros de Asturias. Comun. I Congr. Asturiano Espeleol., (Oviedo), : 1-8.

Gonzalez-Prieto, S., A. Villarino, M. Frean and M.L. Villarino, 1986. - Algunos datos sobre quirópteros de Galicia. Doñana Acta Vert., 13: 186-188.

IBAÑEZ, C., 1988. - Notes on bats from Morocco. Mammalia, 52: 278-281.

IBAÑEZ, C. and J. BENZAL, 1984. - Nuevos datos sobre la presencia del nóctulo gigante Nyctalus lasiopterus (Chiroptera, Vespertilionidae) en España. Doñana Acta Vert., 11: 342-344.

IbAÑEz. C. and R. Fernandez, 1989. - Catálogo de murciélagos de las colecciones del Museo Nacional de Ciencias Naturales. Monografias, Mus. Nac. Cienc. Nat., Madrid, 2 : 1-54.

Martinez, L., 1881. - Fauna de Sierra Morena. Catálogo descriptivo del término de Montoro con indicación de las utilidades y perjuicios que pueden producir al hombre. Madrid.

MEIJIDE, M., 1979. - Catálogo de los quirópteros de la provincia de Santander. Cuadernos Espeleol., Santander, 9-10: 101-116.

Noval, A., 1982. - Zoología Vertebrados. Enciclopedia Temática Asturiana, I. S. Cañada, Gijón.

Otero, C., E. Castien, R. Senosiain and F. Portillo, 1978. - Fauna de Cazorla. Vertebrados. Monografías ICONA, 19: 1-123.

O\%enda, P., A. Noirfalise, R. Tomaselli and W. Trautman, 1979. - Carte de la végétation des États membres du Conseil de l'Europe. Coll. Sauvegarde de la Nature, 16.

Palmeirim, J.M., 1990. - Bats of Portugal : Zoogeography and systematics. Misc. Publ. Mus. Nat. Hist., Univ. Kansas, 82 : 1-53.

PAlmeirim, J.M., M.J. Ramos and D. Dias, 1979. - Bats from Portugal in the collection of Museu Bocage. (Mammalia, Chiroptera). Arq. Mus. Bocage (2 série), 7 : 53-66.

PAZ, O. de and M.J. LOPE, de, 1985. - Note on the distribution of the Geoffroy's bat Myotis emarginatus (Geoffroy, 1806) in the Iberian Peninsula. Doñana Acta Vert., 12 : 333-334.

SamarRa, F.X. and A. Carol, 1986. - Murciélagos incorporados a la colección del Museo de Zoología de Barcelona durante las tres últimas décadas. Misc. Zool., $10: 305-314$.

Sanchez-Canals, J.L. and J. Guitian, 1988. - Inventario dos morcegos de Galicia. (Mammalia, Chiroptera). Cadernos Area Cienc. Biol. Invent. Sem. Est. Galegos, 5: $1-25$. 
Serra-Cobo, J. and F.V. FaUS, 1989. - Nuevas citas y comentarios faunisticos sobre los quirópteros de la Comunidad Valenciana. Mediterránea, Ser. Biol., 11 : 59-76.

Serra-Cobo, J., A. Montori and N. MaCh, 1986. - La cueva de Carradán. Refugio primaveral de una importante población de quirópteros. Pirineos, 128: 121-127.

Sevilla, P., 1988. - Estudio preliminar de los quirópteros del Cuaternario español. Paleontol. Evol., 22: 113-233.

TUPINIER, Y., 1975. - Chiroptères d'Espagne. Systématique-biogéographie. Thèse de Doctorat d'Université, Univ. Cl. Bernard, Lyon, $202 \mathrm{pp}$.

TUPINIER, Y., 1982. - Quiropteros de Espagña. Sistematica, Biogeografia. Cuadernos de Espeleologia (Santander), 9-10: 215-290.

Villota, J. and C. Galan, 1970. - Complejo Leize-Aundia II - Sabe-Saia-Ko-Leizia. Munibe, 22: 175-182. 